\title{
Examining the Effect of a Program Developed to Address Bullying in Primary Schools
}

\author{
(1) Hulya Karatas'1, (1) Candan Ozturk² \\ ${ }^{1}$ Harran University Faculty of Health Sciences, Department of Pediatric Nursing, Şanlıurfa, Turkey \\ ${ }^{2}$ Near East University Faculty of Nursing, Department of Pediatric Nursing, KKTC
}

\begin{abstract}
Aim: The purpose of this study is to evaluate effectiveness of a bullying prevention program developed using an integrated approach, in the short-term and long-term, in primary schools.

Materials and Methods: This study was made using a quasi-experimental control group pretest-posttest design; one of the experimental research methods. This study comprised 113 students receiving $6^{\text {th }}$ grade education at 2 randomly selected schools in the districts of Konak and Karabağlar, in Izmir, Turkey. The data were gathered using the Demographic Data Questionnaire and The Peer Bully Adolescent Form. In the experimental group, students attended a bullying prevention program and their parents and teachers attended seminars for 5 weeks. The data were collected before the training, 2 weeks after the training, at the $6^{\text {th }}$ month, and at 1 year after the training. In the analysis of the data, ANOVA was used in repetitive measurements and t-tests were used in dependent and independent groups with Bonferroni correction.

Results: A statistically significant difference was found among the control and experimental group victim subdimension point averages in the group interaction $(F=68.28, p=0.001)$, time interaction $(F=7.39, p=0.001)$, and group-time interaction $(F=14.04, p=0.001)$. A statistically significant difference was found between the control and experimental group bully subdimension point averages in the group interaction $(F=7.63, p=0.007)$ and time interaction $(F=20.21, p=0.001)$. No significant difference was determined in the group-time interaction $(F=1.10$, $p=0.349)$.

Conclusion: It was found that the bullying prevention program based on the Social Cognitive Theory is effective in decreasing the rates of students who are bullies or are the victims of bullying, and this effect continues in the victims through to the end of the $1^{\text {st }}$ year; however, it becomes nonsignificant in bullies by the end of the $1^{\text {st }}$ year.
\end{abstract}

Keywords: Bullying, bullying prevention program, victim, bully, nursing

\section{Introduction}

Bullying is one of the negative relationships that students experience in schools and it has important negative effects that threaten a child's health and development. Olweus (1) defined bullying as when a student is exposed to the negative behaviors of one or more students in a repeated way, more than one time, meaning this individual is then exposed to bullying or has become a victim. The characteristics of bullying behavior are a real or perceived strength imbalance, an intentional deed with the purpose of harming, and being repetitive (1).

Studies made on bullying in Norway (1), Spain (2), Ireland (3), Finland (4), Australia (5), Greece (6), Malaysia (7), Canada (8), Italy (9), Belgium (10), America (11), Holland (12), Japan (13), and Germany (14) show that bullying is a problem experienced all over the world. 
In the studies made in Turkey (15-18), it was stated that there is a significant increase in the cases of violence and bullying in schools and immediate prevention is required. In the study "Health Behavior in School-aged Children" which was arranged by the World Health Organization, and in which 41 countries took part, the situation of students' being victim and bully over a 12-month period were investigated. Out of 41 countries, Turkey ranked $1^{\text {st }}$ in the victim age group of 11 -year-olds and $10^{\text {th }}$ in the age group of 13 -year-olds. Moreover, Turkey was $3^{\text {rd }}$ in the bully age group of 11-yearolds and $10^{\text {th }}$ in the age group of 13-year-olds. These results show that bullying is an important problem in Turkey as well (19).

In many countries around the world, bullying prevention programs have been applied for years and nation-wide studies have been made on this subject. There are a limited number of studies about bullying prevention in Turkey (2025). Most of the studies are just programs oriented towards students $(21-23,25-27)$. It is stated in the literature that integrated programs including the student, teacher, and parents altogether are more effective in preventing bullying (28). It is also stated that conducting a prevention program in the early adolescent period will be a protective factor in the later life and adulthood of the student (29).

There is a necessity for programs that will provide a healthy learning environment for students, with awareness training that addresses bullying and will include the student, family, and teacher in an integrated way, as well as a necessity for studies that evaluate the long-term effects of these programs. These programs will enable enterprises to work towards a solution by raising awareness concerning the problem of bullying as well as by decreasing the rates of bullying. The purpose of this study is to evaluate the long-term and short-term effectuality of the programs developed to address bullying in primary schools.

\section{Materials and Methods}

\section{Design}

This study was carried out using the "quasi-experimental control group pretest-posttest design" which is one of the experimental methods to evaluate the effectiveness of bullying prevention programs (Figure 1).

\section{Sample}

This study was carried out in 2 primary schools dependent on the Ministry of National Education in the districts of Konak and Karabağlar in Izmir, Turkey. The schools to be included in the study were selected from the half-day public schools that are under the supervision of Konak and
Karabağlar District National Education Directorate. Data from the Izmir National Education Directorate were used to select districts and schools; districts and schools that show similar characteristics were selected. The primary schools in the districts of Konak and Karabağlar were chosen as they serve students from low, middle and high income backgrounds and have mixed student groups. There are a total of 50 primary schools, 47 of which are public and 3 of which are private schools, under the Karabağlar District Directorate of National Education, and 38 of these schools are half-day. There are 70 primary schools, 65 of which are public and 5 of which are private schools under the Konak District Directorate of National Education, and 46 of these schools are half-day.

In Izmir, from the schools that serve under the Konak and Karabağlar District National Education Directorate, two schools were selected among those half-day public schools by a simple random method. As it is stated in the literature that early intervention is important, $6^{\text {th }}$ grade students (approx. 12-year-olds) were taken as samples. The schools to be included in the experimental and control groups and the classes to be selected from the schools were determined by random method.

Two classes were selected from both schools in order to cover the number of samples. An experiment and a control group were generated from both schools. For the determination of the classes, the experimental group was selected from the morning classes and the control group was selected from the afternoon classes. D and B classes were included in the sample under the experimental group and $D$ and $F$ classes were included in the sample under the control group. Before starting the research, the class lists of the sample classes were requested and the number of classes was determined according to the number of students.

The study was carried out between February 2007 and June 2011. Schools and branches that would be in the experimental and control group were randomly selected and $6^{\text {th }}$ grade students were taken as the sample. The demographic data of the students are given in Table I.

In order to determine the sample size, an analysis was made by taking the Type II error 0.20 (80\% power), Type I error 0.05 significance level, and the data in the study by Ayas (20), and it was found that the sample size should be at least 32 for each group. Thus, 2 classes from each school were included in the study.

According to the power analysis, it was calculated that there should be at least 32 students in a group. As the 
number of students in the classes in the experimental group was 29 and 27, no students were excluded from the class and the training for the prevention of bullying was conducted with the whole class. The posttests were taken from 97 students, however 77 students, whose names/nicknames match with the first measurement, were included in the posttests (1 year after the interference), because of reasons such as some of the students had left the school or some new students had arrived.

The t-test was used in order to determine the difference between the averages of the students' ages in the experimental and control groups; $x^{2}$ analysis was made in order to determine the difference between the groups in terms of gender, and it was found that there was no significant difference between the groups in terms of age and gender (Table I, p>0.05).

The t-test was used in order to determine the difference between the victim and bully pretest point averages of the students in the experimental and control groups, and it was found that there was no significant difference (Table II, $p>0.05)$. The fact that there was no change between

\begin{tabular}{|c|c|c|c|c|c|c|}
\hline \multirow[t]{2}{*}{ Group } & \multicolumn{4}{|c|}{ Age } & \multirow{2}{*}{$\mathbf{t}$} & \multirow{2}{*}{ p } \\
\hline & \multicolumn{2}{|l|}{$\mathbf{n}$} & \multicolumn{2}{|c|}{$X \pm S D$} & & \\
\hline Experimental & \multicolumn{2}{|l|}{56} & \multicolumn{2}{|c|}{$11.5 \pm 0.6$} & \multirow{2}{*}{0.587} & \multirow{2}{*}{0.558} \\
\hline \multirow[t]{2}{*}{ Control } & \multicolumn{2}{|l|}{57} & \multicolumn{2}{|c|}{$11.6 \pm 0.5$} & & \\
\hline & \multicolumn{4}{|c|}{ Gender } & \multirow{3}{*}{$\mathbf{X}^{2}$} & \multirow{3}{*}{$\mathbf{p}$} \\
\hline \multirow[t]{2}{*}{ Group } & \multicolumn{2}{|c|}{ Female } & \multicolumn{2}{|c|}{ Male } & & \\
\hline & $\mathbf{n}$ & $\%$ & $\mathbf{n}$ & $\%$ & & \\
\hline Experimental & 30 & 53.7 & 26 & 46.3 & \multirow{2}{*}{0.435} & \multirow{2}{*}{0.510} \\
\hline Control & 27 & 47.4 & 30 & 52.6 & & \\
\hline
\end{tabular}

Table II. Comparison of the bully and victim pretest point averages of the students

\begin{tabular}{|c|c|c|c|c|}
\hline \multirow[t]{2}{*}{ Group } & \multicolumn{2}{|c|}{$\begin{array}{l}\text { Victim Subdimension } \\
\text { Points }\end{array}$} & \multirow[t]{2}{*}{$\mathbf{t}$} & \multirow{2}{*}{ p } \\
\hline & $\mathbf{n}$ & $X \pm S D$ & & \\
\hline Experimental & 56 & $76,21 \pm 22.23$ & \multirow{2}{*}{0.577} & \multirow{2}{*}{0.565} \\
\hline \multirow[t]{3}{*}{ Control } & 57 & $78.49 \pm 19.62$ & & \\
\hline & \multicolumn{2}{|c|}{ Bully Subdimension Points } & \multirow{2}{*}{$\mathbf{t}$} & \multirow{2}{*}{$\mathbf{p}$} \\
\hline & $\mathrm{n}$ & $X \pm S D$ & & \\
\hline Experimental & 56 & $58.17 \pm 13.24$ & \multirow{2}{*}{1.572} & \multirow{2}{*}{0.119} \\
\hline Control & 57 & $62.03 \pm 12.83$ & & \\
\hline
\end{tabular}

the groups in terms of the age, gender, victim, and bully subdimensions shows that the groups were homogenous.

\section{Research Instruments}

The data were collected using the Demographic Data Collection Form and The Peer Bully scale-adolescent form (30). The demographic data collection form consists of questions such as nickname, name, and age.

\section{The Peer Bully scale-adolescent Form}

The Peer Bully scale-adolescent form developed by Pişkin and Ayas (30) consists of 2 scales called the "Bully scale" and the "Victim scale". This scale consists of 53 items covering physical bullying, verbal bullying, bullying by isolation, bullying by spreading rumor, bullying with threatening objects, sexual bullying, and victim subdimensions. The scale is graded as "never" (1) and "almost every day" (5), and as the number increases, the cases of being a bully or victim increase. In this study, the sexual bully and victim subdimensions could not be used due to the fact that it was not permitted by the Directorate of National Education. For this reason, the lowest point score possible was 43 and the highest point possible was 215 , taken from the bully and victim subdimensions. Pişkin and Ayas (30) stated the Cronbach alpha internal consistency coefficient to be 0.93 for the total Victim scale and 0.92 for the total Bully scale. In this study, the Cronbach $\alpha$ coefficient was computed as 0.88 for the total Victim scale and 0.91 for the total bully scale.

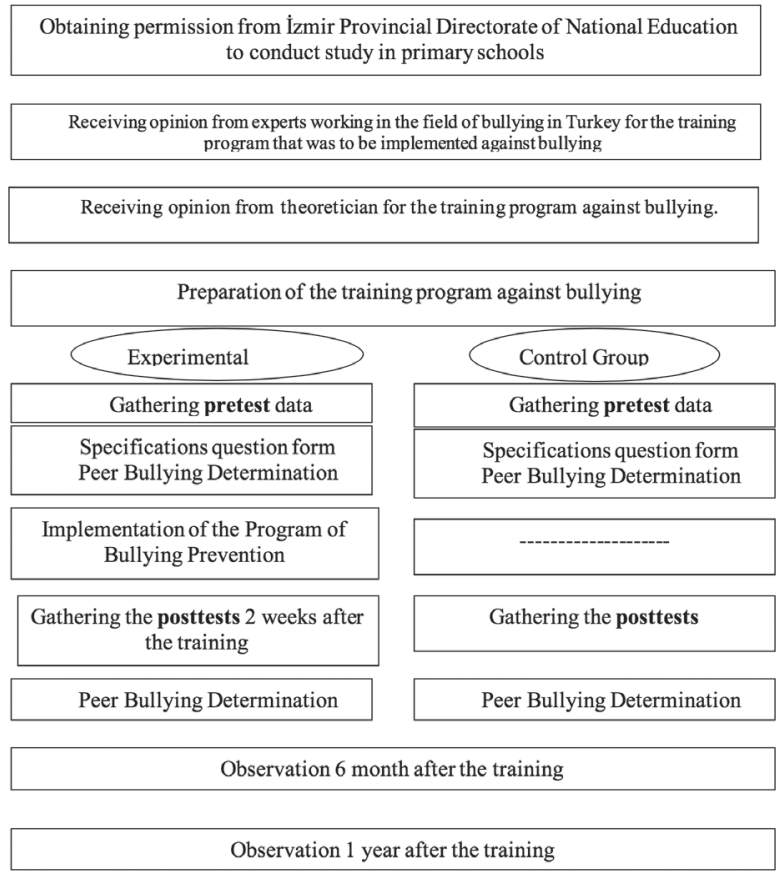

Figure 1. Study plan 


\section{Application of the Training Program}

In this study, a bullying prevention program was prepared in 2 steps. In the first step, the conceptual framework of the bullying prevention program was prepared according to Bandura's Social Cognitive Theory. In this study, a training program was prepared in accordance with reciprocal determinism, self-sufficiency, self-regulation, and the indirect learning principles of Social Cognitive Theory (31).

The second step was to take expert opinions. In this study, a training program for bullying was prepared by taking opinions from different disciplines. A Bullying Training Content Questionnaire was prepared by the researchers in accordance with the literature and sent to the experts via e-mail. Experts were also requested to state training subjects that they thought should be in the student, teacher, and parent training program, and those subjects that were not in the questionnaire, but they thought should be. A scanning method was chosen to reach these experts in Turkey. Consequently, the authors of 50 studies made in Turkey before and during 2009 were sent e-mails. In order to reach all of these experts, reminder e-mails were also sent; however, just 15 experts replied back. All of these responders stated that there should be "awareness training" and "problem solving skills" at the highest level in the student, teacher, and parent training programs. The training contents were formed in line with these expert opinions.

\section{Program Carried Out with the Students}

The training program for students was conducted as weekly 40-minute sessions over a 5 -week period. The program lasted for 7 weeks with sessions in which pretest and posttest data were collected. The program was held in the seminar hall of the school on the same day, at the same hour, every week, due to the fact that only counseling courses were allowed for the application of the program by the school administrators.

Within the program content carried out with the students, there were awareness training sessions that included information about bullying, sessions in which scenarios about the direct and indirect aspects of bullying were solved with problem solving techniques, an intervention techniques session in which what to do in a cases of being exposed to bullying was discussed, and a session oriented towards antibullying activities. In the student training, the methods of slides, videos, pictures, scenarios, mnemonic games about the subject, acting roles, question-answer activities, and the preparation and presentation of posters were used.

The study data were collected 4 times: before the training (pretest: with 113 students), 2 weeks after the training (posttest 1: with 112 students), 6 months after (posttest 2: with 87 students), and 1 year after (posttest 3: with 97 students). The attendance rate was $86 \%$. In total,

\begin{tabular}{|c|c|c|c|c|c|c|}
\hline $\begin{array}{l}\text { Time } \\
\text { Groups }\end{array}$ & $\begin{array}{l}\text { Pretest } \\
X \pm S D\end{array}$ & $\begin{array}{l}\text { Posttest } 1 \\
\mathrm{X} \pm \mathrm{SD}\end{array}$ & $\begin{array}{l}\text { Posttest } 2 \\
X \pm S D\end{array}$ & $\begin{array}{l}\text { Posttest } 3 \\
X \pm S D\end{array}$ & \multirow{3}{*}{$\mathbf{F}$} & \multirow{3}{*}{$\mathbf{p}$} \\
\hline Experimental & $73.5 \pm 18.3$ & $54.4 \pm 11.5$ & $52.7 \pm 9.8$ & $55.0 \pm 10.8$ & & \\
\hline \multirow[t]{4}{*}{ Control } & $78.4 \pm 19.2$ & $76.8 \pm 23.3$ & $81.9 \pm 26.5$ & $90.5 \pm 22.4$ & & \\
\hline & & & & Group & 68.28 & 0.001 \\
\hline & & & & Time & 7.39 & 0.001 \\
\hline & & & & Group*Time & 14.04 & 0.001 \\
\hline
\end{tabular}

Table IV. The effect of the program addressed to bullying on the bully subdimension points

\begin{tabular}{|c|c|c|c|c|c|c|}
\hline $\begin{array}{l}\text { Time } \\
\text { Groups }\end{array}$ & $\begin{array}{l}\text { Pretest } \\
X \pm S D\end{array}$ & $\begin{array}{l}\text { Posttest } 1 \\
X \pm S D\end{array}$ & $\begin{array}{l}\text { Posttest } 2 \\
X \pm S D\end{array}$ & $\begin{array}{l}\text { Posttest } 3 \\
X \pm S D\end{array}$ & \multirow{3}{*}{$\mathbf{F}$} & \multirow{3}{*}{$\mathbf{p}$} \\
\hline Experimental & $58.5 \pm 13.5$ & $46.9 \pm 4.9$ & $47.5 \pm 5.8$ & $50.3 \pm 9.4$ & & \\
\hline Control & $62.1 \pm 14.1$ & $55.2 \pm 16.1$ & $52.1 \pm 10.6$ & $54.2 \pm 11.7$ & & \\
\hline & & & & Group & 7.63 & 0.007 \\
\hline & & & & \multirow{2}{*}{$\begin{array}{r}\text { Time } \\
\text { Group*Time }\end{array}$} & 20.21 & 0.001 \\
\hline & & & & & 1.10 & 0.349 \\
\hline
\end{tabular}


the analyses of only 77 students could be made as the passwords of some of the students did not match or they did not have the 6-month or 1-year follow-up data, or they had changed schools.

\section{Parental Participation}

In studies carried out with parents, the inadequate attendance of parents is a common problem. In order to mitigate this problem, a letter was prepared about the importance of the training program and the attendance to the program for the parents of the students in the experimental group, and these were sent to the families by the school administration. Moreover, information was given about the study and the parents' questions were answered at parent training sessions. These parent training sessions took place twice a day, each session lasted for 60 minutes and 26 parents attended the training. In the parent training session content, there was awareness training for bullying, the negative results of bullying, adolescence, and subject of communication with an adolescent.

\section{Program Carried Out with the Teachers}

In the $5^{\text {th }}$ training session of the program, training was given for the teachers. In line with the suggestions of the experts, school administrators were also included in this training. In the training session content for teachers, there was awareness training for bullying, the negative results of bullying, activities that could be done to prevent bullying school-wide, and subjects that dealt with the relationship between bullying and teacher attitudes. As just $6^{\text {th }}$ grade classroom teachers were to take part in the study, training materials were shared with the school administrators attending the study and it was aimed to inform all of the teachers.

\section{Statistical Analysis}

The study data were assessed using SPSS Software in a computer environment, ANOVA for repetitive measurements, and t-test for dependent and independent groups with Bonferroni correction (32).

\section{Ethical Dimensions of the Study}

In order to conduct this study, written permission was taken from the Dokuz Eylül University Faculty of Nursing Ethics Committee (18.10.2007/1169), the Izmir Provincial Directorate for National Education, and from the parents of those students involved, and verbal permission was taken from the students. All of the parents allowed their children to take part in the study.

\section{Results}

In this category, the findings of this study are given under 2 titles, namely, the effect of the program on the victim and on the bully subdimension points of students.

In Table III, a comparison of the averages of the Peer Bully scale victim subdimensions are given. A significant difference was found between the experimental and control group victim subdimension point averages according to the group ( $F=68.28, p=0.001)$, time $(F=7.39, p=0.001)$, and group*time $(F=14.04, p=0.001)$.

In this study, it was found that there was a significant difference between the measurements before the training, the 6-month, and 1-year measurements in the experimental group in which the bullying prevention program was applied. It was also found that the program carried out with the students in the experimental group caused more of a decrease in the victim levels than for those students in the control group, and this was a long-term situation.

In Table IV, the averages of The Peer Bully scale bully subdimensions are given. In the results of the analysis, a statistically significant difference was found between the bully subdimension point averages according to the group $(F=7.63, p=0.007)$ and time $(F=20.21, p=0.001)$. No significance difference was confirmed for the group and time interaction $(F=1.10, p=0.349)$.

\section{Discussion}

In this category, findings obtained from the data of the study are discussed with the titles of victim and bully subdimensions and, additionally, suggestions are offered.

\section{The Effect of the Program for Bullying on the Victim Subdimension Points of the Students}

In this study, it was determined that the bullying prevention program is effective in decreasing the victim subdimension points of the students in the experimental group and that this effect continues in the measurements of the 6-month and 1-year follow-up (Table III). This finding is similar to some studies in the literature that evaluate to effectiveness of programs developed to prevent bullying $(1-4,6,8,11,20,22-25,27)$. This differs from the findings of some studies stating that bullying prevention programs are not effective $(5,7,9,21,26)$. In the systematic collected work, Vreeman and Carrol (28) analyzed the effectuality of bullying prevention programs and they determined that integrated programs were more effective compared to other programs. In this study, the effectiveness of the 
program can be assessed as a result of its being integrated and the attendance of the students, teachers, and parents.

There are a limited number of studies in which the long-term effectiveness of programs developed for bullying prevention are analyzed in the literature $(1,5,6,12)$ and the results also differ. In the review study made by Mytton et al. (29), which evaluates the effectiveness of programs developed to decrease violence and bullying in schools, it was stated that a 12-month follow-up was conducted in only 7 studies.

In this study, it was found that while the experimental group victim points decreased, the control group victim points increased. It is thought that in a branch in the control group, being exposed to bullying with the change in class and peer relationships and victim points increased in the 1-year follow-up. It was stated in the study by Totan and Yöndem (33) that as peer relationships increase, cases of being the bully increase but cases of being the victim decrease.

\section{The Effect of the Program for Bullying on the Bully Subdimension Points of the Students}

In this study, it was determined that the bullying prevention program was effective in decreasing the bully subdimension points of those students in the experimental group; however, this effect did not continue in the measurements of the 6-month and 1-year follow-up (Table IV). This finding is similar to the results of other studies $(3,4,12,23)$. The fact that the effectiveness of the program continued into the 6-month follow-up showed that it was effective in the long-term. In a study in which follow-ups were made for less than 6 months (20), it was found that the program was not effective for the rates of being bullied. This result is different from the findings of the present study. In the 1-year follow-up of this study, the fact that there was not a significant difference in the bully rates between the groups made us think that in order to make effectiveness continue, further training was necessary 1 year after the initial training. Fekkes et al. (12) stated that the program should be repeated every year for greater effectiveness.

\section{Study Limitations}

The inadequate attendance of the parents, the inclusion of only $6^{\text {th }}$ grade classroom teachers in the study, and students dropping out or changing classes while the followup data during the $1^{\text {st }}$ year were being collected were the restrictions of this study.

\section{Conclusion}

That the program is effective in decreasing the victim points 2 weeks after and at the 6-month and 1-year followup and is effective in decreasing the bully points 2 weeks after and at the 6-month follow-up; however, it is not effective at the 1-year follow-up.

In line with the results obtained in this study, it is suggested that:

That training should be repeated every year in programs applied for bullying prevention, mnemonic training should be made, and activities about bullying should be planned.

It is recommended to conduct studies in which the negative consequences of bullying are defined and the effectiveness of the programs developed for these negative consequences are evaluated.

\section{Ethics}

Ethics Committee Approval: Written permission was taken from the Dokuz Eylül University Faculty of Nursing Ethics Committee (18.10.2007/1169).

Informed Consent: Consent forms were filled out by all participants.

Peer-review: Externally peer-reviewed.

\section{Authorship Contributions}

Concept: H.K., C.Ö., Design: H.K., C.Ö., Data Collection or Processing: H.K., Analysis or Interpretation: C.Ö., Literature Search: C.Ö., Writing: H.K., C.Ö.

Conflict of Interest: No conflict of interest was declared by the authors.

Financial Disclosure: The authors declared that this study received no financial support.

\section{References}

1. Olweus D. Bullying at school: what we know and what we can do. Oxford: Blackwell Publishers 1993.

2. Ortega R, Lera M). The sevile anti-bullying in school project. Agressive Behavior 2000; 26:113-23.

3. O'Moore MA, Minton JS. Evulation of the effectiveness of an anti-bullying programme in primary schools. Aggressive Behavior 2005; 31:609-22.

4. Salmivalli C, Kaukiainen A, Voeten M. Anti-bullying intervention: implementation and outcome. Br J Educ Psychol 2005; 75:46587.

5. Hunt $\mathrm{C}$. The effect of an education program on attitudes and belief about bullying and bullying behavior in junior secondary school students. Child and Adolescent Mental Health 2007; 12:21-6.

6. Andreou E, Didaskalou E, Vlachou A. Evaluating the effectiveness of a curriculum-based anti-bullying intervention program in 
Greek primary schools. Educational Psychology 2007; 27:693711.

7. Yaakub NF, Haron F, Leong CC. Examining the efficacy of the Olweus prevention programme in reducing bullying: the Malaysian experience. Procedia Social and Behavioral Sciences 2010; 5:595-8.

8. Beran TN, Tuty L, Steinrath G. An evaluation of a bullying prevention program for elemantary schools. Canadian Journal of School Psychology 2004; 19:99-116.

9. Baldry CA, Farrıngton PD. Evoluation of an intervention program for the reduction of bullying and victimization in school. Aggressive Behavior 2004; 30:1-15.

10. Stevens V, Oost VP, Bourdeaudhuij D. The effects of an antibullying intervention programme on peers' attitudes and behaviour. Journal of Adolescence 2000; 23:21-34.

11. Orpinas P, Horne AM, Staniszewski D. School bullying: changing the problem by changing the school. School Psychology Review 2003; 32:431-44.

12. Fekkes M, Pijpers IMF, Verloove-Vanhorick PS. Effects of antibullying school program on bullying and health complaints. Arch Pediatr Adolesc Med 2006; 160:638-44.

13. Hara $H$. Justifications for bullying among lapanese schoolchildren. Asian Journal of Social Psychology 2002; 5:197204.

14. Scheithauer $H$, Hayer $T$, Petermann F, Jugert G. Physical, verbal and relational forms of bullying among german students: age trends, gender differences and correlates. Aggressive Behavior 2006; 23:261-75.

15. Alikaşifoğlu M, Erginöz E, Ercan O, Uysal Ö, Albayrak-Kaymak D. Bullying behaviours and psychosocial health: results from a cross-sectional survey among high school students in İstanbul, Turkey. Eur / Pediatr 2007; 166:1253-60

16. Karaman Kepenekci Y, Çınkır Ş. Bullying among Turkish high school students. Child Abuse \& Neglect 2006; 30:193-204.

17. Kapcı EG. İlköğretim öğrencilerinin zorbalığa maruz kalma türünün ve sıklığının depresyon, kaygı ve benlik saygısıyla ilişkisi. Ankara Üniversitesi Eğitim Bilimleri Fakültesi Dergisi 2004; 37:113.

18. Pişkin, M. Okullarımızda yaygın bir sorun: okul zorbalığı. VII. Ulusal Psikolojik Danışma ve Rehberlik Kongresi Kongresi (2003).

19. Currie C, Gabhainn SN, Godeau E, et al. Inequalities in young people's health. HBSC International Report from The 2005/2006 survey. WHO, Health Policy Children and Adolescents No:5, 2008.
20. Ayas T. The effectiveness of preventing bullying behaviors one program based on whole school approach. Unpublished doctoral dissertation, Ankara University, 2008. Ankara.

21. Dölek N. Öğrencilerde zorbaca davranışların araştırııması ve önleyici bir program modeli. Unpublished doctoral dissertation, Marmara University, 2002, İstanbul.

22. Kartal H, Bilgin A. Illköğretim öğrencilerine yönelik bir zorbalık karşıtı program uygulaması: okulu zorbalıktan arındırma programı. Eğitimde Kuram ve Uygulama 2007; 3:207-27.

23. Şahin M, Akbaba S. Investigating the efficiency of emphaty training program for preventing bullying behaviors in primary schools. Kastamonu Eğitim Dergisi 2010; 18,331-42.

24. Takış Ö. Analysis of the impact of coping with bullying program designed for secondary schools]. Ankara Üniversitesi Eğitim Bilimleri Enstitüsü, 2006, Ankara.

25. Uysal A. Şiddet karşıtı programlı eğitimin öğrencilerin çatışma çözümleri, şiddet eğilimleri ve davranışlarına yansıması. 1. Şiddet ve Okul: Okul ve Çevresinde Çocuğa Yönelik Şiddet ve Alınacak Tedbirler Sempozyumu, 2006, İstanbul.

26. Günay \$̧, Can G. The Effectiveness of a Peer Support Program on Coping with Bullying. Türk Psikolojik Danışma ve Rehberlik Dergisi 2018; 8:266-94.

27. Akcan A, Akcan F, Savran S. An initative programme for prevention of bullying behavior for elementary school student. Journal of Research in Education and Teaching 2016; 5:259-65.

28. Vreeman RC, Carroll AE. A systematic review of schoolbased interventions to prevent bullying. Archives Pediatrics Adolescent Medicine 2007; 161:78-88.

29. Mytton J, DiGuiseppi C, Gough D, Taylor R, Logan S. Schoolbased secondary prevention programmes for preventing violence. Cochrane Database of Systematic Reviews 2006; 3:CD004606

30. Pişkin $M$, Ayas T. Akran zorbalığı belirleme ölçeği ergen formunun geliştirilmesi. IX. Ulusal Psikolojik Danışma ve Rehberlik Kongresi, 2007, Çeşme.

31. Bandura A. Social cognitive theory in personality. In: A. P. Lawrence, P. J. Oliver, Handbook of personality. Theory and Research. 1999.

32. Akgül A. Tıbbi araştırmalarda istatistiksel analiz \& SPSS uygulamaları. Ankara: 2005, Emek Ofset.

33. Totan T Yöndem ZD. The investigation of bullying in adolescence related to parent and peer relations. Ege Eğitim Dergisi 2007; 2:53-68. 